\title{
Influence of chitosan on hematological and histopathological changes in mice infected with Brucella melitensis immunized with Rev-1 vaccine
}

\author{
M.A. Al-Khafaji ${ }^{1}$ and H.H. Al-Sultany ${ }^{2}$ \\ ${ }^{1}$ Department of Pathology and Poultry Diseases, College of Veterinary Medicine, Al-Qasim Green University, \\ ${ }^{2}$ Veterinary Directorate, Ministry of Agriculture, Babylon, Iraq \\ Email: ${ }^{1}$ muna_saheb2002@yahoo.com, ${ }^{1}$ muna200@vet.uoqasim.edu.iq, ${ }^{2}$ madh632004@yahoo.co.uk
}

(Received January 25, 2019; Accepted May 12, 2019)

\begin{abstract}
This study aimed to assess the changes of blood cells constitutions and study the histopathological sections of liver and spleen in dual sexes mice infected with brucella melitensis and the role of chitosan supplement with and without Rev-1 vaccine in enhancing the inflammatory proses, two experiments were undertaken on 100 albino mice, aged 8-10 weeks for 60 days, first experiment done on 50 males and second one done on 50 females. Results of hematological analysis showed that there are significant increase at $\mathrm{P}<0.001$ of white blood cells count $\mathrm{WBC}\left(\times 10^{3}\right)$, red blood cells count $\mathrm{RBC}\left(\times 10^{6}\right)$, hematocrit $(\mathrm{HCT})$, mean corpuscular value $(\mathrm{MCV})$, mean corpuscular hemoglobin $(\mathrm{MCH})$, mean corpuscular hemoglobin concentration (MCHC), lymphocyte (LY\%), granulocyte (GR) and lymphocytes $\mathrm{m} / \mathrm{mm}^{3}$ (LYM) in males treated groups comparing with females, the highest values were in immunized infected mice with chitosan diet supplement compared to infected animals. The histopathological lesions recorded there is presence of chronic inflammatory reaction characterized by mononuclear cell infiltration with presence of granulomatous lesion in the liver of immunized animals, presence of mild to moderate lesions characterized by hyperplasia of lymphoid tissue in spleen and small granulomatous lesions in liver of immunized animals fed diet with chitosan supplement.
\end{abstract}

Keywords: Chitosan, Histopathological examination, Rev-1 vaccine, Hematological analysis, Brucella melitensis Available online at http://www.vetmedmosul.com, (C) 2020, College of Veterinary Medicine, University of Mosul.

This is an open access article under the CC BY 4.0 license (http://creativecommons.org/licenses/by/4.0/).

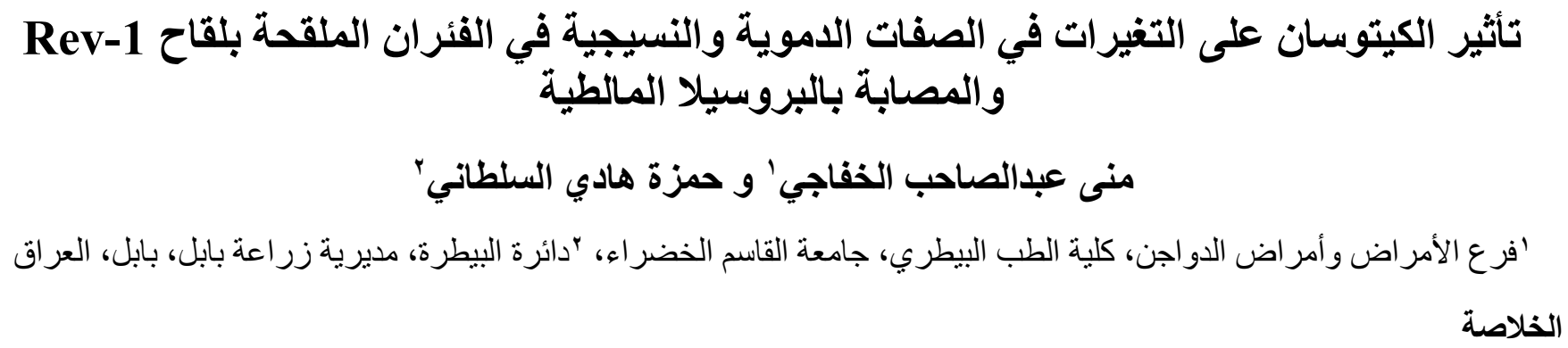

هذه الدر اسة هدفت الى التحري عن التغير ات في الصفات الدموية ودراسة المقاطع النسيجية المأخوذة من كبد وطحال الفئران من كلا

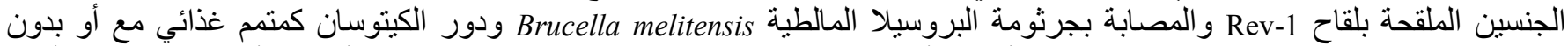

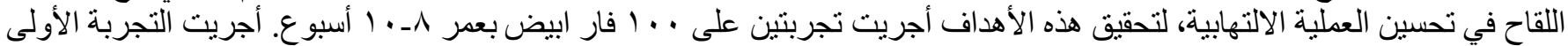

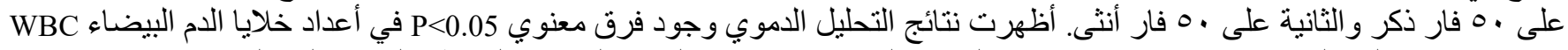

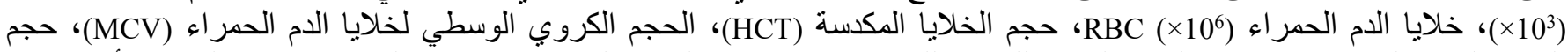

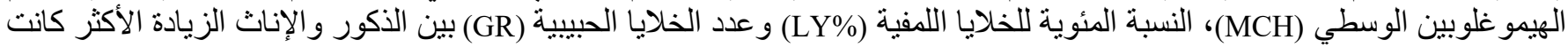

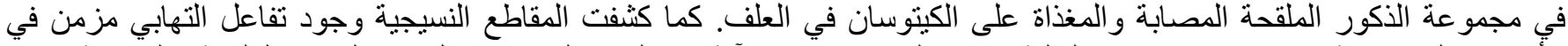

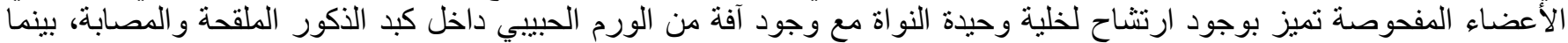

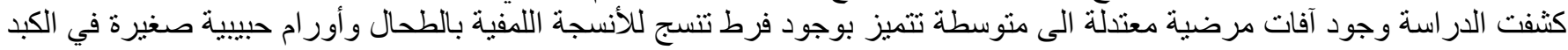
في الحيو انات المصابة الملقحة و المغذاة على الكيتوسان في العلف. 


\section{Introduction}

Brucellosis is an infectious zoonotic disease causes important economic and public health problem in human and animals, particularly abortion and infertility in natural host (1). Brucellosis are endemic in different countries worldwide including Iraq in addition, Middle East, Mediterranean area, Asia, Africa and South America (2).These bacteria cause $95.6 \%$ of the economic losses in cattle and buffalo in livestock (3) and over 500,000 infections every year in human (4), and less than 5\% death human however patient remain asymptomatically carrier for years (5). There are several routes of brucella infection include oro- digestive tract, aerosol, conjunctiva (6) Human infection with Brucella occur either through contact with infected animals, through one person to the other (7) and from consumption of infected animal products (8). Brucella melitensis is persistable in the blood of intraperitoneally infected mice for several weeks (9). Extreme hematological complications and abnormalities with mild anemia and leukopenia have been frequently associated with acute brucellosis, but pancytopenia and thrombocytopenia are less frequently encountered (10). The pathogenesis of pancytopenia in brucellosis has not been clearly understood, it seems to be multifactorial. Several possible mechanisms have been suggested for pancytopenia caused by brucellosis, such as hemophagocytosis, hypersplenism, bone marrow granulomas, bone marrow hypoplasia, and immune destruction (11). Chitosan is biocompatible, biodegradable, nontoxic, renewable biopolymer produced by alkali treatment of chitin, the second most abundant natural polysaccharide used in a biomedical material, as it exhibits a wide variety of biological activities, such as antitumor activities (12), immunostimulating, antiallergic effects (13), hemostatic agent and anticoagulant effects (14), anti- inflammatory activities (15), bacteriostatic as anti-biofilm-associated infections effects (16) woundhealing (17), and anti-fungal activities (18).

\section{Material and methods}

\section{Experimental design \\ First Experiments (male experiment)}

Fifty albino male mice, were divided randomly into five groups 10 each and treated as following; $1^{\text {st }}$ group was vaccinated with Rev 1 vaccine $(\mathrm{S} / \mathrm{C})$, two doses, each dose $0.2 \mathrm{ml}$, repeated after two weeks $(\mathrm{GI}) .2^{\text {nd }}$ group was vaccinated as $1^{\text {st }}$ group and supplemented with chitosan 1 $\mathrm{g} / \mathrm{kg}$ diet (19) daily (G2). $3^{\text {rd }}$ group was supplemented with chitosan $1 \mathrm{~g} / \mathrm{kg}$ diet to the end of the experiment (G3). $4^{\text {th }}$ group was infected with $0.3 \mathrm{ml}$ virulent $B$. melitensis $1 \times 10^{-8}$ CFU I/P (20) and considered positive control group (G4). $5^{\text {th }}$ group was orally administrated with PBS served as negative control group (G5).

\section{Second experiment (female experiment)}

Done as first experiment but on females. In both experiments, 30 days post immunization, animals of $1^{\text {st }}, 2^{\text {nd }}$, $3^{\text {rd }}$ and $4^{\text {th }}$ groups were injected $\mathrm{I} / \mathrm{P}$ with $0.3 \mathrm{ml}$ of bacterial suspension containing $1 \times 10^{-8} \mathrm{CFU}$ of viable virulence $B$. melitensis, at 60 days post injection, all animals were sacrificed, blood samples were taken for hematological examination and tissues from liver and spleen for histopathological examination.

\section{Lio-vac rev-1 vaccine}

It is a commercial vaccine against Brucellosis in ewes, lambs and kids aged $3-6$ months which is composed of Brucella melitensis Rev-1 strain 1-2 $\times 10^{-9} \mathrm{CFU}$ per dose (manufactured by syvasa, Spain), manuf. date / 5. 2017 Exp. date 5.2018. the vaccine obtained from Al-Nahdha Veterinary Laboratories / Baghdad.

\section{Bacterial isolate}

The virulent Brucella melitensis isolate obtained from Al-Nahdha Veterinary Laboratories /Baghdad, growth and biochemical tests were performed for isolation, diagnosis, confirmation according to (20), the cultural characteristics were studied depending on colonies morphology (color, size, consistency and density) on growth media and other biochemical tests. Culture media: Tryptic Soya Agar (TSA) and Tryptic Soya Broth (TSB): (Rashmi diagnostics / India). Blood Agar and Peptone Water Media: (Oxoid /USA). Catalase test was performed according to (20); the babbles production indicated a positive reaction. Oxidase test was performed according to (20). Confirming the diagnosis of the isolate was performed using VITAK system. Preparation of chitosan diet: The pellets were grinded by food grinder and weighed, then $1 \mathrm{gm}$ of chitosan (fatsorb ${ }^{\circledR}$ ) added to each kilogram of assorted commercial pellets, mixed well, converted to paste by passing through meat grinder to mould the paste into the original pellets form, then left exposed to air drying in room temperature (21).

\section{Determination of challenge dose of $\boldsymbol{B}$. melitensis}

Activation of bacteria and bacterial counting done according to (20). The challenge dose was $1 \times 10^{-8} \mathrm{CFU} / \mathrm{ml}$ (22).

\section{Histopathological examination}

Histological sections done according to (23).

\section{Hematological examination}

Blood was collected immediately after anesthesia, directly from the heart using insulin syringes $1 \mathrm{ml} 60$ days post infection, samples analyzed by an automated blood counter (Abacus junior Vet Diatron Hematology Analyzer, Hungary). The total white blood cells (WBC), red blood 
cell (RBC), hemoglobin (HGB), platelets (PLT) and hematocrit (HCT) levels were measured.

\section{Statistical Analysis}

The statistical analysis was carried out for data by using factorial experiment in (CRD) method according to $(24,25)$.

\section{Results}

\section{Hematological analysis}

The results of whole white blood cells count (Table 1) show high significant differences between treated groups $(\mathrm{P} \leq 0.01)$ at 60 days post infection with B.melitensis compared to non-infected control group in both male and female although higher value obtained in immunized group compared to groups with chitosan supplement with or without immunization. There is a decrease in red blood cells (RBCs) count in infected groups in both sexes compared to treated groups while the highest was in immunized animals fed diet supplement of chitosan in both sexes.

Also, the results revealed an increasing level in granulocytes $\left(\mathrm{GR} \mathrm{m} / \mathrm{mm}^{3}\right)$ in the immunized groups with or without chitosan (G2 and 3) compared to infected group with diet supplement of chitosan only (G1) in both sexes, the highest values in males. The $\mathrm{MCH}, \mathrm{MCHC}$ and $\mathrm{MCV}$ values show an increase in infected groups (G5) in both sexes comparing with non-infected groups (G4) and the higher values in immunized groups with and with-out chitosan (G1, 2 and 3) in both sexes (Table 1 and 2).

Table 1: Hematological profile of infected male groups with different treatment 60 days post infection

\begin{tabular}{lccccc}
\hline Parameters & G1 & G2 & G3 & G4 & G5 \\
\hline WBC $(\times 103)^{* *}$ & $5.19 \pm 0.01 \mathrm{~d}$ & $9.530 \pm .04 \mathrm{a}$ & $8.20 \pm 0.02 \mathrm{~b}$ & $7.60 \pm 0.02 \mathrm{c}$ & $4.06 \pm 0.141 \mathrm{e}$ \\
RBC $(\times 106)^{*}$ & $7.25 \pm 0.05 \mathrm{c}$ & $7.63 \pm 0.01 \mathrm{a}$ & $7.61 \pm 0.42 \mathrm{e}$ & $6.12 \pm 0.01 \mathrm{~d}$ & $7.85 \pm 0.07 \mathrm{~b}$ \\
HCT $^{* *}$ & $31.34 \pm 0.04 \mathrm{bc}$ & $32.98 \pm 0.05 \mathrm{~b}$ & $30.54 \pm 0.01 \mathrm{~cd}$ & $37.27 \pm 1.86 \mathrm{a}$ & $30.33 \pm 0.39 \mathrm{~d}$ \\
MCV $^{* *}$ & $40.00 \pm 1.00 \mathrm{a}$ & $49.50 \pm 0.06 \mathrm{a}$ & $43.00 \pm 0.04 \mathrm{a}$ & $42.00 \pm 0.01 \mathrm{a}$ & $19.50 \pm 1.45 \mathrm{~b}$ \\
MCH $^{* *}$ & $13.70 \pm 0.60 \mathrm{c}$ & $13.50 \pm 0.40 \mathrm{c}$ & $16.80 \pm 0.01 \mathrm{a}$ & $16.60 \pm 0.30 \mathrm{a}$ & $13.50 \pm 0.10 \mathrm{c}$ \\
MCHC** & $318.00 \pm 2.00 \mathrm{~d}$ & $339.00 \pm 0.61 \mathrm{~b}$ & $322.00 \pm 1.0 \mathrm{c}$ & $333.00 \pm 1.09 \mathrm{dc}$ & $349.00 \pm 3.50 \mathrm{a}$ \\
LY \%** & $60.30 \pm 0.01 \mathrm{~d}$ & $82.20 \pm 0.10 \mathrm{ab}$ & $79.05 \pm 0.05 \mathrm{~b}$ & $54.75 \pm 0.95 \mathrm{~d}$ & $36.60 \pm 3.80 \mathrm{e}$ \\
GR $^{* *}$ & $29.60 \pm 0.10 \mathrm{~d} \mathrm{e}$ & $57.35 \pm 7.95 \mathrm{a}$ & $38.90 \pm 0.06 \mathrm{c}$ & $48.25 \pm 2.75 \mathrm{ac}$ & $16.70 \pm 0.02 \mathrm{e}$ \\
LYM $^{* *}$ & $6.13 \pm 0.04 \mathrm{c}$ & $6.74 \pm 0.01 \mathrm{~b}$ & $3.12 \pm 0.01 \mathrm{f}$ & $1.50 \pm 0.20 \mathrm{~h}$ & $5.22 \pm 0.11 \mathrm{~d}$ \\
\hline Di
\end{tabular}

Different letters indicate significant differences between treated groups at $* \mathrm{P}<0.05$ and $* * \mathrm{P}<0.01$.

Table 2: Hematological profile of infected female groups with different treatment 60 days post infection

\begin{tabular}{lccccc}
\hline Parameters & G1 & G2 & G3 & G4 & G5 \\
\hline WBC $(\times 103)^{* *}$ & $6.18 \pm 0.03 \mathrm{e}$ & $9.28 \pm 0.02 \mathrm{a}$ & $6.27 \pm 0.01 \mathrm{c}$ & $6.80 \pm 0.01 \mathrm{~b}$ & $4.25 \pm 0.06 \mathrm{~d}$ \\
RBC $(\times 106)^{*}$ & $7.37 \pm 0.04 \mathrm{bc}$ & $7.37 \pm 0.14 \mathrm{bc}$ & $7.98 \pm 0.01 \mathrm{a}$ & $6.41 \pm 0.05 \mathrm{bc}$ & $7.37 \pm 0.01 \mathrm{bc}$ \\
HCT $^{* *}$ & $32.75 \pm 0.19 \mathrm{bc}$ & $35.27 \pm 0.73 \mathrm{a}$ & $36.18 \pm 0.81 \mathrm{a}$ & $3.73 \pm 0.04 \mathrm{c} \mathrm{d}$ & $31.58 \pm 0.02 \mathrm{bc}$ \\
MCV $^{* *}$ & $44.00 \pm 0.01 \mathrm{a}$ & $48.00 \pm 0.44 \mathrm{a}$ & $46.50 \pm 0.06 \mathrm{a}$ & $41.00 \pm 004 \mathrm{a}$ & $43.50 \pm 0.02 \mathrm{a}$ \\
MCH** $^{* *}$ & $15.75 \pm 0.60 \mathrm{~b}$ & $16.70 \pm 0.10 \mathrm{a}$ & $15.10 \pm 0.09 \mathrm{~b}$ & $15.50 \pm 0.35 \mathrm{~b}$ & $15.40 \pm 0.05 \mathrm{~b}$ \\
MCHC $^{* *}$ & $355.00 \pm 4 \mathrm{bc}$ & $349.00 \pm 3 \mathrm{c}$ & $326.50 \pm 0.5 \mathrm{~d}$ & $374.00 \pm 3.00 \mathrm{a}$ & $360.00 \pm 0.05 \mathrm{~b}$ \\
LY $^{* *}$ & $35.05 \pm 1.75 \mathrm{e}$ & $53.55 \pm 6.35 \mathrm{~d}$ & $69.00 \pm 0.10 \mathrm{c}$ & $84.80 \pm 1.01 \mathrm{ab}$ & $87.70 \pm 0.01 \mathrm{a}$ \\
GR $^{* *}$ & $30.60 \pm 0.01 \mathrm{e}$ & $55.25 \pm 5.7 \mathrm{ab}$ & $43.85 \pm 4.65 \mathrm{c}$ & $39.20 \pm 0.30 \mathrm{~d}$ & $15.80 \pm 0.03 \mathrm{e}$ \\
LYM $^{* *}$ & $4.32 \pm 0.04 \mathrm{e}$ & $8.16 \pm 0.04 \mathrm{a}$ & $2.26 \pm 0.30 \mathrm{~g}$ & $0.76 \pm 0.04 \mathrm{i}$ & $5.77 \pm 0.03 \mathrm{c}$ \\
\hline
\end{tabular}

Different letters indicate significant differences between treated groups at $* \mathrm{P}<0.05$ and $* * \mathrm{P}<0.01$.

\section{Histopathological examination}

Results of histopathological changes of infected animal with $B$. melitensis revealed presence of coagulative necrosis in liver parenchyma, congestion with neutrophils infiltration of central vein and sinusoids (Fig1: A,B) other sections of liver showed fibrosis of portal area with infiltration of inflammatory cells (Fig1: C) while spleen section of the same group showed fibrin network deposition and neutrophils infiltration in red pulp with depletion of white pulp (Fig1: D), however histopathological section of immunized animal at 60 days post infected with $B$. melitensis showed aggregation of mononuclear cells around blood vessels with proliferation of Kupffer cells in the liver (Fig2: E, F). Histological section of immunized animal fed diet supplement with chitosan at 2 months post infected with $B$. melitensis showed severe infiltration of mononuclear cells around central vein and bile duct in liver portal area with hyperplasia of white pulp (Fig3: G,I, J). 


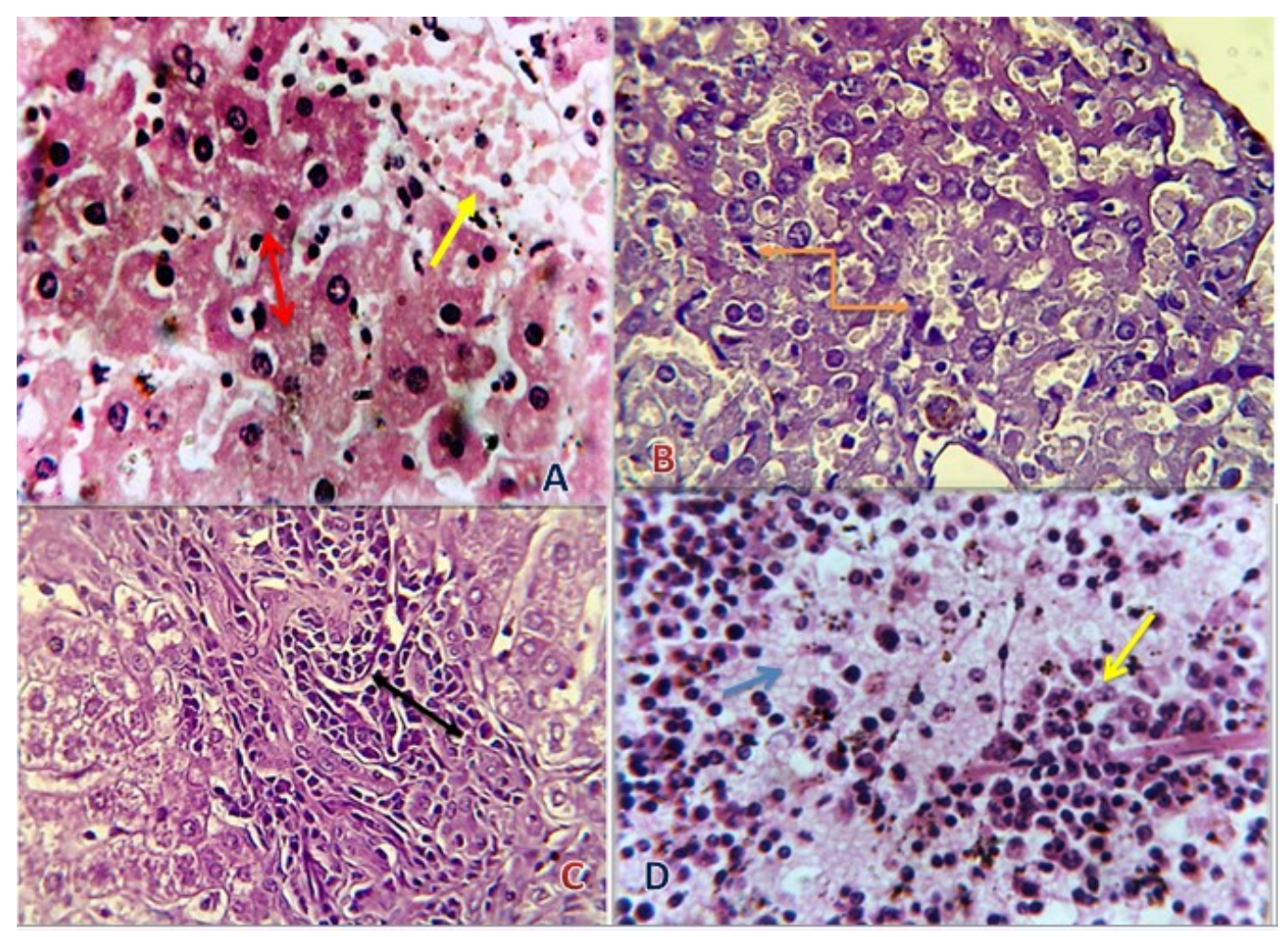

Figure 1: Histopathological section of infected animal with B. melitensis 60 days post infection. A: liver, congestion of central vein with neutrophils in its lumen (yellow arrow), with coagulative necrosis (red arrow) through liver parenchyma, H\&E, 132x. B: liver, severe congested of dilated sinusoids containing inflammatory cells (orange tow head arrow), H\&E stain, 400x. C: liver, inflammatory cells in fibrosis portal area (black arrow), H\&E stain, 400x. D: spleen, deposition of fibrin network (blue arrow) and neutrophils infiltration in red pulp which lead to depletion of white pulp (yellow arrow), H\&E, 132x.

\section{Discussion}

\section{Hematological analysis}

The results of WBCs agree with (27) who mentioned that white blood cell count increased significantly in vaccinated animals after vaccination up to $90^{\text {th }}$ day post challenge in comparison with initial decrease, circulating antibodies induced by vaccination intensely reduce persistence of bacteria in the blood following challenge. The $B$. melitensis bacteria is lasts for at least 2 weeks in the blood of infected mice after intraperitoneally injection. They are located primarily in extracellular then found inside erythrocytes (9). This theory explains the decrease in red blood cells (RBCs) count in infected groups in both sexes comparing with treated groups while the highest value in immunized animals fed diet supplement of chitosan in both sexes. Also results revealed that there is an increasing level in granulocytes $(\mathrm{GR} \mathrm{m} / \mathrm{mm} 3)$ in the immunized groups with or without chitosan comparing with infected group fed with diet supplemented with chitosan only in both sexes, the highest in males this agrees with (28) who explained that neutrophil phagocytic activity increased about threefold in infected groups with brucellosis probably due to it is the consider first immune associated cells in the host defense against Brucella invasion and replication in phagocytic cells, such as macrophages and dendritic cells (29), moreover chitosan act as vaccine adjuvant the effect of chitosan was first demonstrated by (30). The mechanism of bacterial growth inhibition is thought to be that the cationically charged amino-group may combine with anionic components such as $\mathrm{N}$-acetylmuramic acid, sialic acid and neuraminic acid, on the cell surface, and may suppress bacterial growth by impairing the exchanges with the medium, chelating transition meal ions and inhibiting enzymes (31). The MCH, MCHC and MCV values were in infected groups comparing with non-infected groups and the higher values in immunized groups with and without chitosan in both sexes this agrees with (32) who suggested that anemia was the most common hematologic sign of brucellosis. Anemia prevalence in patients with and without occupational exposure history. 

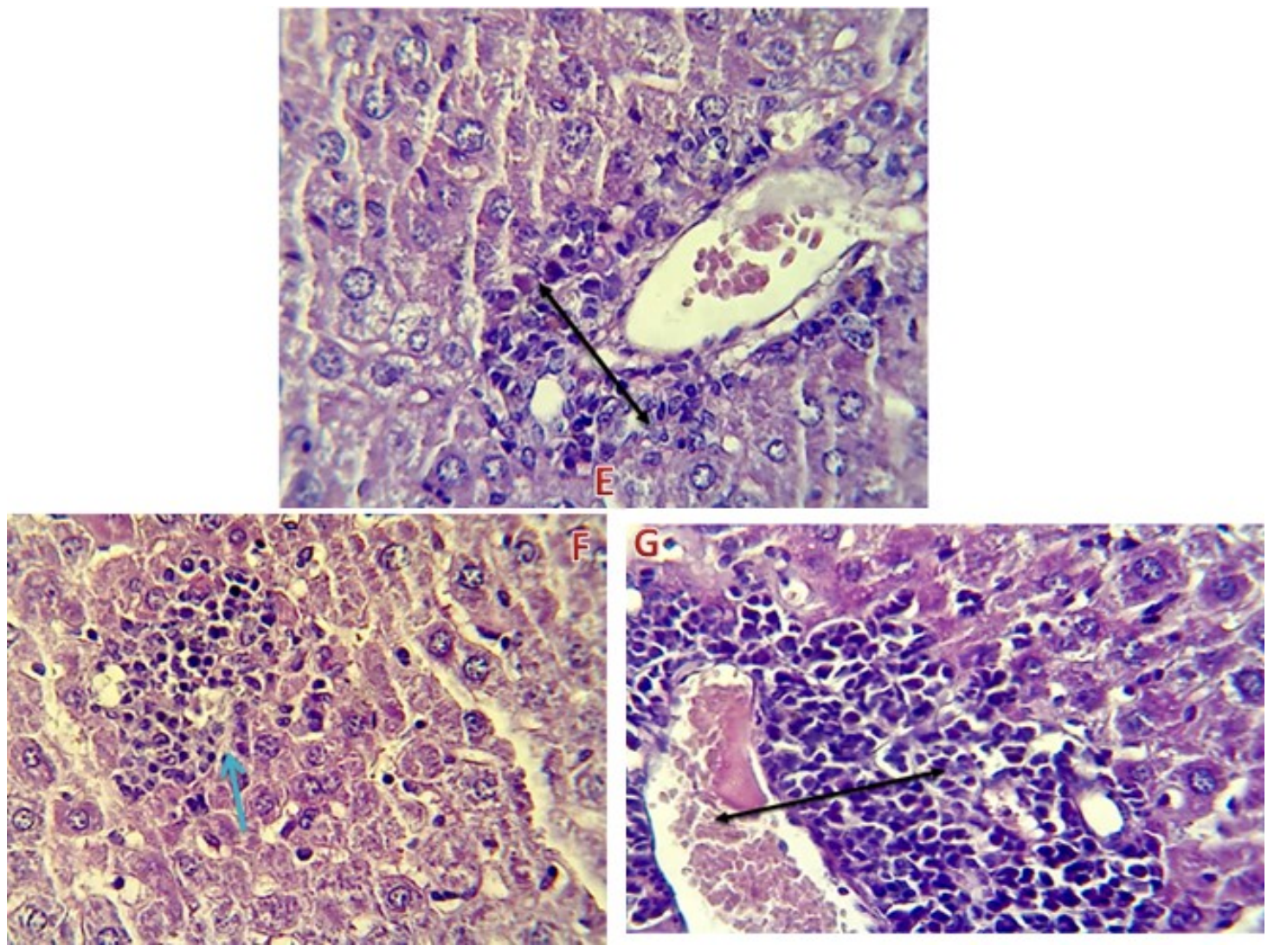

Figure 2: Histopathological section of immunized animal at 60 days post infected with B. melitensis (H\&E stain, 400x). E: liver, mononuclear cells aggregation around blood vessels with proliferation of Kupffer cells (black arrow). F: liver, mononuclear inflammatory cells aggregation around central vein in parenchyma (blue arrow). G: liver, of immunized animal fed diet supplement with chitosan at 2 months post infected with B. melitensis shows mononuclear cells aggregation around congested central vein (black arrow).

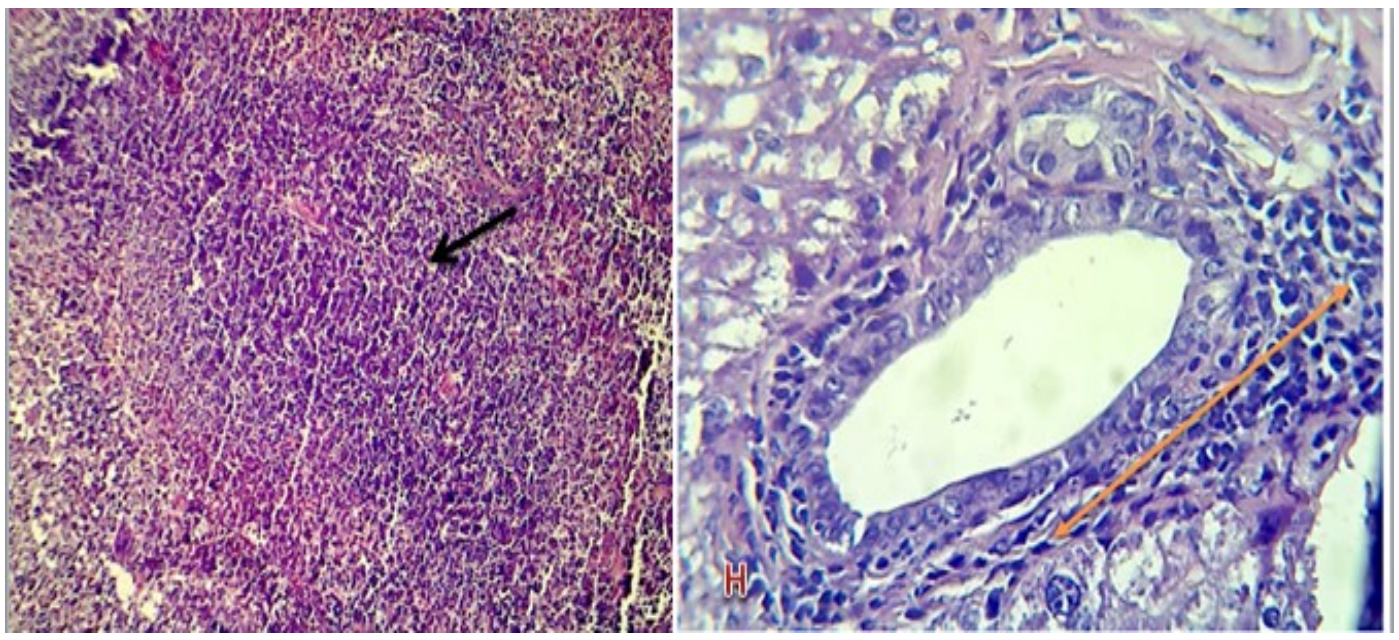

Figure 3: Histological section of immunized animal fed diet supplement with chitosan at 2 months post infected with $B$. melitensis. H: liver, shows severe mononuclear cells infiltrated around bile duct in portal area, H\&E stain, 400X. (red arrow). I: hyperplasia of white pulp (blue arrow), H\&E stain, 100X. 


\section{Histopathological examination}

The histopathological changes in examined organs showed moderate inflammatory cells particularly neutrophils and mononuclear cells recorded in examined organs, these lesions may indicate that the strain of $B$. melitensis cause suppurative reaction due to pathogen associated molecular pattern (PAMP) of these pathogen attached with toll-like receptor 4,5 and 9 that lead to activate events end with activation of nuclear factor kappabeta $(\mathrm{NF}-\mathrm{k} \beta)$ which activates kappa gene in the nuclei of macrophage to stimulate expression of pro-inflammatory genes that encoded pro- inflammatory cytokines such as IL1, TNF-a and IL-12 as well as chemokines particularly IL-8 a potential attracted factor for neutrophils leading to suppurative reaction, this idea was correlated with (33) who previously observed that both innate and acquired immune responses used in the protective host against brucellosis and innate immune response consist of neutrophils, macrophage/ monocyte, dendritic cells as well as natural killer cells, these cells have pattern recognition protein (PRR) that recognizes PAMPs leading to production of proinflammatory cytokines, chemokines and type I and II IFN which are important factors in host defense, clearance infection occur by activated $\mathrm{T}$ and $\mathrm{B}$ cells by chemokines and cytokines in addition to inflammatory reaction that initiated by pro inflammatory cytokines (34).

The present findings recorded necrosis in the liver and spleen, these two organs are the targets of reticuloendothelial system of Brucella in which the pathogen can survive and replicate in these organs as well as disseminated to other organs of the body, necrosis maybe due to oxidative stress induced by brucellosis that causes damage of protein, carbohydrate, cell membrane and DNA (35).

Granulomatous lesions are found in immunized animals with or without chitosan may indicate that the body attempt be localized and destroy the pathogen due to granulomatous reaction is consider as a strong body defense against virulent pathogens, as well as Brucella infection is usually associated with development of granulomatous reaction (36) these reaction occur as a result of Brucella antigens can stimulated pro inflammatory cytokines such as IL-1, 1L-12 which play role in development of cell mediated immune response associated with granulomatous lesions development.

However, in the present results recorded hepatitis and splenitis in infected animals, these lesion may indicated hematogenous spread of virulent strain of B. melitensis, hepatitis is a common lesion in human brucellosis but not in animals, also (37) recorded lymphoplasmacytic infiltration in the renal interstitial tissue of swine infected with $B$. abortus and multifocal lymphoplasmacytic infiltration in the liver with pyogranuloma and necrosis, the less degree of lesions in the immunized animal with or without chitosan may indicated that chitosan do seem to have essential role against oxidative damage scavenging or dimensioning activity of ROS, these result was agreed with (38), who demonstrated that antioxidant such as vitamin $\mathrm{C}$ and vitamin $\mathrm{E}$ can inhibited activity of NF-kB and depress cytokine production.

The mild to moderate pathological lesions in immunized animals with or without chitosan supplement diet may be due to good immune response provided by Rev -1 vaccine and chitosan that killed most of the pathogen at site of inoculation and few of them disseminated to internal organs that killed by activated macrophages that form granulomatous lesions, these idea was agreement with (39), who recorded that chitosan can activated both cellular and humoral immune response also (40) recorded high antibodies titers and activated CD4 T cells in animals fed diet supplement with chitosan.

\section{Conclusion}

Overall, chronic infection with brucella melitensis causes anemia, chitosan as food supplement acts as immune stimulator with Rev-1 vaccination against infection with brucella melitensis and enhancing inflammatory proses by elevation of WBCs, GR, $\mathrm{MCH}, \mathrm{MCHC}$ and $\mathrm{MCV}$, hyperplasia of lymphoid tissue and formation of granulomatous reaction in spleen and liver respectively.

\section{Acknowledgement}

The research was supported by College of Veterinary Medicine, Baghdad and Al-Qasim Green University.

\section{References}

1. Waqas A, Ke Z, Zheng L. Establishment of chronic infection: Brucella's stealth strategy. Front Cell Infect Microbiol. 2016;15(6):30. doi: $10.3389 /$ fcimb.2016.00030.

2. Franco MP, Mulder M, Gilman RH, Smits HL. Human brucellosis. Lancet Infect Dis. 2007;7(12):775-786.

3. Singh BB, Dhand NK, Gill JP. Economic losses occurring due to brucellosis in Indian livestock populations. Prev Vet Med. 2015;119(3-4):211-215.

4. Durward M, Radhakrishnan G, Harms J, Bareiss C, Magnani D, Splitter GA. Active evasion of CTL mediated killing and low quality responding $\mathrm{CD}^{+} \mathrm{T}$ cells contribute to persistence of brucellosis. PLoS ONE. 2012;7:e34925.

5. Bossi P. Bichat guidelines for the clinical management of brucellosis and bioterrorism-related brucellosis. Euro Surveill 2004;9:e15-e16.

6. Scholz HC, Nöckler K, Göllner CG. "Brucella inopinata sp nov, isolated from a breast implant infection,". Inter J Sys Evol Microbiol. 2010;60(4):801-808.

7. Pappas G, Papadimitriou P, Christou L, Akritidis N. Future trends in human brucellosis treatment. Expert Opin Invest Drugs. 2006;15:1141-1149.

8. De Figueiredo P, Thomas A, Ficht A, Carlos A, Rossetti A, Garry A. Pathogenesis and immunobiology of Brucellosis: Review of Brucella host interactions. Am J Pathol. 2015;185:1505-1517. 
9. Vitry MA, Delphine HMs, Michael D, Katrin H, Arnaud M, Frédéric L, Jean V, Carl De Tz, David P, Jean L, Eric M. Brucella melitensis invades murine erythrocytes during infection. Infect Immun. 2014;82(9):3927-3938.

10. Pappas G, Kitsanou M, Christou L, Tsianos E. Immune thrombocytopenia attributed to brucellosis and other mechanisms of Brucella-induced thrombo-cytopenia. Am J Hematol. 2004;75:139141.

11. Grigoriou I, Giannakaki A, Pagoni M, Themistoklis D Karmiris C. Mitsouli, E. Nikiforakis. Extreme hematological abnormalities associated with human brucellosis: Report of two cases. Haema. 2003;6:93-96.

12. Santosh K, Joonseok K, Hyerim K, Gupta MK, Dutta PK. A new chitosan thymine conjugates: Synthesis, characterization and biological activity. Inter J Biol Macromol. 2012;50:493-502.

13. Vo TS, Kim JA, Ngo DH, Kong CS, Kim SK. Protective effect of chitosan oligosaccharides against FceRI-Mediated RBL-2H3 mast cell activation. Process Biochem. 2012;47:327-330.

14. Wang TJ. Assessing the role of circulating, genetic, and imaging biomarkers in cardiovascular risk prediction. Circ. 2011;123:551-565.

15. Chung MJ, Park JK, Park YI. Anti-inflammatory effects of lowmolecular weight chitosan oligosaccharides in IgE-antigen complexstimulated RBL-2H3 cells and asthma model mice. Int Immunopharmacol. 2012;12:453-459.

16. Cobrado L, Silva A, Azevedo MM, Pina C, Rodrigues AG. In vivo antibiofilm effect of cerium, chitosan and hamamelitannin against usual agents of catheter-related bloodstream infections. J Antimicrob Chemother Pmid. 2013;68(1):126.

17. Jayakumar R, Prabaharan M, Sudheesh PT, Nair SV, Tamura H. Biomaterials based on chitin and chitosan in wound dressing applications. Biotechnol Adv. 2011;29:322-337.

18. Qin YK, Xing RG, Liu S, Li KC, Meng XT, Li RF, Cui JH, Li B, Li PC. Novel thiosemicar- bazone chitosan derivatives: Preparation, characterization, and antifungal activity. Carbohydr Polym. 2012;87:2664-2670.

19. Alkhafajy M.A.J. The role of chitosan and immunization with Brucella melitensis Rev1- vaccine in reducing the pathogenesis and oxidative stress induced by virulent Brucella melitensis in albino mice. $\{\mathrm{PhD}$ thesis $]$ Baghdad university College of Veterinary Medicine; 2017. 36-38p.

20. Quinn PJ, Carter ME, Markey B, Carter GR. Clinical veterinary microbiology. $6^{\text {th }}$ ed. London: Mosby; 2004. 261-267 p.

21. Shakir SA. Effect of hypercholesterolemia, chitosan and whole sonicated E. coli Ags on immune response and pathological changes in mice infected with $E$. coli $(\mathrm{O}: 127)$ isolated from children suffering from diarrhea. [MSc thesis] Baghdad: College of Veterinary Medicine; 2012. $30 \mathrm{p}$.

22. Milles A, Misra S, Irwin J. The estimation of bactericidal power of the blood. J Hyg. 1938;38:732.
23. Luna LG. Manual of histological staining of force institute of pathology. $3^{\text {rd }}$ ed. New York: McGraw hill book; 1968. 134-135 p.

24. Al-Zubaidy K, Al-Falahy M. Principles and procedures of statistics designs and experimental designs. Ministry of Higher Education and Scientific Research, University of Duhok, College of Agriculture, Iraq; 2018. 239-267 p.

25. SAS. SAS Users Guide: Statistical version 6.12. North Carolina: SAS institute Inc; 2012. $722 \mathrm{p}$.

26. Kumar A, Yadav SK. Assessment of hematological bio markers during vaccination and challenge of Brucella melitensis in Goats. Int $\mathrm{J}$ Vaccines Vaccin. 2017;4(2):1-6.

27. Tsevelma N, Odgerel O, Dariimaa D, Batkhuu J. Anti-Brucella activity of Caryopteris mongolica Bunge root extract against Brucella melitensis infection in mice. Complement Altern Med. 2018;18:144.

28. Copin R, Vitry M, Hanot D, Machelart A, De C, Vanderwinden J, Magez S, Akira S, Ryffel B, Carlier Y, Letesson J, Muraille E. In situ microscopy analysis reveals local innate immune response developed around Brucella infected cells in resistant and susceptible mice. PLoS Pathog. 2012;8:1-5.

29. Suzuki K. Okawa Y, Hashimoto K. Protecting effect of chitin and chitosan on experimentally induced murine candidiasis. Microbiol Immunol. 1984;8(28):903-912.

30. Aleksandra B, Anna W, Bogumila P, Alojzy R, Lukasz L. Antibacterial and antifungal activity of chitosan. ISAH. 2005;2:1-3.

31. Abdulkadir K, Tekin T, Mehmet T, Gülali A, İsmail N, Firat Z, Hayrettin A. Erythrocytes parameters in the course of Brucellosis. Abant Med. 2013;39(2):36-39.

32. Droge W. Free radicals in the physiological control of cell function. Physiol Rev. 2002;82:47-95.

33. Loguercio C, Federico A. Oxidative stress in viral and alcoholic hepatitis. Free Radic Biol Med. 2003;34(1):1-10.

34. Pierce JD, Cackler AB, Arnett MG. Why should you care about free radicals. RN. 2004;67(1):38-42.

35. Alwan MJ. Study of some aspects of nocardiosis in animals in Iraq [PhD dissertation]. Baghdad: College of Veterinary Medicine, University of Baghdad; 1996; 98 p.

36. William C, Steven C, Olsen C, Jack W, Betsy J, Mitchell V, Palmer E, Jensen M, Halling A. An overview of Diagnostic characterization of a feral swine herd enzootically infected with Brucella. J Vet Diagn Invest. 2015;19:227-237.

37. Stiff A, Trikha P, Mundy B, McMichael E, Mace TA, Benner B, Kendra K, Campbell A, Gautam S, Abood D. Nitric oxide production by myeloid-derived suppressor cells plays a role in impairing $\mathrm{Fc}$ receptor-mediated natural killer cell function. Clin. Cancer Res. 2018;24:1891-1904.

38. Smith A, Perelman M, Hinchcliffe M. Chitosan: A promising safe and immune-enhancing adjuvant for intranasal vaccines. 2014;10(3):797807.

39. Zaharoff DA, Rogers CJ, Hance KW, Schlom J, Greiner JW. Chitosan solution enhances both humoral and cell-mediated immune responses to subcutaneous vaccination. Vaccine. 2007;25(11):2085-94. 